\title{
Is MDMA Present in Hair Samples Consistent with Reported Ecstasy Use?
}

\author{
A.B. Scholey ${ }^{*}, 1$, L. Owen ${ }^{1}$, J. Gates ${ }^{1}$, J. Rodgers ${ }^{2}$, T. Buchanan ${ }^{3}$, J. Ling ${ }^{4}$, T. Heffernan ${ }^{5}$, P. Swan ${ }^{1}$, \\ C. Stough ${ }^{1}$ and A.C. Parrott ${ }^{6}$
}

${ }^{1}$ Brain Sciences Institute, Swinburne University, 3122 Vic, Australia

${ }^{2}$ Newcastle University, Newcastle Upon Tyne, NE1 7RU, UK

${ }^{3}$ Westminster University, London, W1B 2UW, UK

${ }^{4}$ Keele University, ST5 5BG, UK

${ }^{5}$ Northumbria University, NE1 8ST, UK

${ }^{6}$ Swansea University, Wales, SA2 8PP, UK

Keywords: Ecstasy, MDMA, self-report, internet, hair samples.

\section{INTRODUCTION}

Our group has conducted several Internet investigations into the biobehavioural effects of recreational use of MDMA (Ecstasy) and other psychosocial drugs [1-5]. They have relied on self-reports of drug use. Here we report a new study examining the relationship between self-reported Ecstasy use and traces of MDMA found in hair samples.

\section{METHODS}

While in the laboratory, 49 unpaid undergraduate volunteers ( 23 female, 26 male) performed an internet-based assessment battery which included mood scales, and the UEL Drug use questionnaire which asks for history and current drug use. They also provided a hair sample for determination of exposure to drugs including MDMA over the previous month. This was tested using the Society for Hair Testing guidelines [6]. The presence of an array of recreational and other drugs was assessed, although this paper only covers the MDMA findings.

\section{RESULTS}

MDMA was present in 22 of the 49 hair samples. Selfreports of Ecstasy use and presence of MDMA in hair samples were highly consistent $(\mathrm{p}<0.00001)$. The main disagreements between hair and self-reports occurred in the lighter Ecstasy/MDMA users (1-9 times lifetime). However many of these participants would had taken the drug some time previously, hence explaining why it was no longer present in their hair. Both subjective and objective measures of MDMA presence predicted significantly lower selfreported ratings of happiness, and higher self-reported stress. The full findings from this study are being presented elsewhere [7].

*Address correspondence to this author at the Brain Sciences Institute, Swinburne University, 3122 Vic, Australia; Tel: +61 (0) 3921 48932; Fax: +61 (0) 3921 45525;

E-mails: AScholey@groupwise.swin.edu.au,andrew@scholeylab.com

\section{DISCUSSION AND CONCLUSION}

We have shown a good correspondence between selfreport and objective assessment of exposure to MDMA. This is consistent with the concordance between recreational Ecstasy and MDMA, as noted by a review [8], and in a laboratory study where every weekend 'Ecstasy' user had MDMA in their saliva [9]. Finally, the present study demonstrates that the internet has high potential utility as a research medium, which complements more traditional laboratory methods into the sequelae of recreational drug use.

\section{ACKNOWLEDGEMENT}

This work was in part supported by an Australian Research Council Discovery grant to C. Stough, K. Owens and E. Ogden.

\section{REFERENCES}

[1] Rodgers J, Buchanan T, Scholey AB, Heffernan TM, Ling J, Parrott AC. Patterns of drug use and the influence of gender on self reports of memory ability in ecstasy users: a web based study. J Psychopharmacol 2003; 17: 379-86.

[2] Ling J, Heffernan TM, Buchanan T, Rodgers J, Scholey AB, Parrott AC. Effects of alcohol on subjective ratings of prospective and everyday memory deficits. Alcohol Clin Exp Res 2003; 27: 970-4.

[3] Scholey AB, Parrott AC, Buchanan T, Heffernan T, Ling J, Rodgers $\mathrm{J}$. Increased intensity of Ecstasy and polydrug usage in the more experienced recreational Ecstasy/MDMA users: a www study. Addict Behav 2004; 29: 743-52.

[4] Rodgers J, Buchanan T, Pearson C, et al. Differential experiences of the psychobiological sequelae of ecstasy use: quantitative and qualitative data from an internet study. J Psychopharmacol 2006; 20: 437-46.

[5] Parrott AC, Rodgers J, Buchanan T, Ling J, Heffernan T, Scholey AB. Dancing hot on ecstasy: physical activity and thermal comfort ratings are associated with the memory and other psychobiological problems reported by recreational MDMA users. Hum Psychopharmacol 2006; 21: 285-98.

[6] Society for Hair Testing. Recommendation for hair testing in forensic cases. Forensic Sci Int 2004; 145: 83-4. 
[7] Scholey AB, Owen L, Gates J, et al. Hair MDMA samples are consistent with reported ecstasy use: finding from an internet study investigating effects of Ecstasy on mood and memory. Neuropsychobiology 2011; 63: 15-21.

[8] Parrott AC. Is Ecstasy MDMA? A review of the proportion of ecstasy tablets containing MDMA, dosage levels, and the changing perceptions of purity. Psychopharmacology 2004; 173: 234-41.
[9] Parrott AC, Lock J, Conner, AC, Kissling C, Thome J. Dance clubbing on-MDMA and during abstinence from MDMA: prospective neuroendocrine and psychobiological changes. Neuropsychobiology 2008; 57: 165-80.

Received: November 4, 2010

(c) Scholey et al.; Licensee Bentham Open.

This is an open access article licensed under the terms of the Creative Commons Attribution Non-Commercial License (http://creativecommons.org/licenses/ by-nc/3.0/) which permits unrestricted, non-commercial use, distribution and reproduction in any medium, provided the work is properly cited. 